\title{
135ste BESTUURSVERGADERING.
}

\author{
11 JUL,I 1871.
}

Tegenwoordig de heeren Gevers Deynoot (Voorzitter), Robidé van der Aa, Bleeker, van Limburg Brouwer, Dumontier, Hoffiman, 's Jacob, Meinsma en Niemann. De heer Bachiene tengevolge van ambtsbezigheden met kennisgeving afwezig.

De Voorzitter deelt mede dat de heeren 's Jacob en Meinsma, aan wie schriftelijk kennis is gegeven van humne benoeming tot lid van het bestuur, bij missive verklaard hebben die betrekking te aanvaarden.

De Voorzitter heet beide genoemde heeren, alsmede den heer Bleeker, welkom in de bijeenkomst van het Bestuur en beveelt hun de belangen van het Instituut aan.

I. Voor de bibliotheek zijn ingekomen de volgende werken: Van het Historisch Genootschap:

Verhooren en andere bescheiden betreffende het rechtsgeding van Hugo de Groot, uitgegeven door R. Fruin.

Memorien en adviezen van Cornelis Pieterszoon Hooft. Van de keizerlijke academie te St. Petersburg:

Bulletin deel XV, blad 17-24, deel XVI, blad 1-4.

Mémoires deel XVI, no. 1-8.

Van de keizerlijke academie te Weenen:

Sitzung-berichte der math. Naturwissensch. Classe 1871 no. XV-XVII.

Van de Royal geographical society:

Proceedings deel $\mathrm{XV} \mathrm{n}^{0} .1$.

Van de Asiatic Society of Bengal:

Bibliotheca Indica Old series no. 225-226. - New series $n^{0} .222$. 
Van den schrijver, den heer A. W. P. Verkerk Pistorius, een ex. van zijn geschrift:

Studien over de inlandsche huishouding in de Padangsche bovenlanden.

Van professor Angelo de Gubernatis:

La Rivista Europea 2e jaarg. deel 3, afl. 2.

II. De Voorzitter deelt mede dat zijn ontvangen de volgende missives :

1o. Van het Bestuur van het Congres International des Sciences Géographiques, Cosmographiques et Commerciales, waarbij herinnerd wordt dat de bijeenkomst van het Congres zal plaats hebben van 14-22 Augustus en de uitnoodiging wordt herhaald tot het zenden van afgevaardigden.

De Secretaris zegt dat de heer Obreen verhinderd wordt het congres bij te wonen, maar dat de heer Blommendal voornemens is zich naar Antwerpen te begeven, en deze alsdan gaarne het Instituut op het congres zal vertegenwoordigen. Aan den Secretaris wordt bevoegdheid gegeven, zoo nog andere leden gezind mochten zijn het Congres bij te wonen, deze, evenals den heer Blommendal, van een geloofsbrief te voorzien.

Op de vraag van den heer Bleeker: of de vertegenwoordiger of vertegenwoordigers van het Instituut een mandaat zullen ontvangen? geeft de vergadering eenparig een ontkennend antwoord, zoodat zij geheel zullen uitdrukken hun individueel gevoelen.

20. Van de heeren Enschedé en Zonen ten geleide eener rekening tot een bedrag van $f 739,80$ voor drukkosten van het werk van professor Roorda, de Wayangverhalen.

De Secretaris deelt hieromtrent mede dat in het archief geen contract omtrent de uitgave van dit werk is gevonden. Alleen vindt men in de notulen vermeld dat in de vergadering van " 28 December 1864 besloten is het werk van professor Roorda te drukken op kosten van het Instituut en het na voltooiing rond te zenden aan de leden, aan welk besluit indertijd uitvoering is gegeven.

De vergadering is, naar anleiding van deze mededeeling, eenparig van oordeel dat het Instituut tot voldoening der ingezonden rekening verplicht is en machtigt dus den penningmeester tot betaling der rekening.

3o. Van den penningmeester van het Instituut (die verhinderd wordt tegenwoordig te zijn), waarin wordt medegedeeld 
dat uit het laatste schrijven van de firma Winsser, de Lange en Co. te Batavia, van 28 April 1871, blijkt dat eenige OostIndische leden op de laatste circulaire van het Bestuur $f 12$ hebben betaald, doch hun achterstand stilzwijgend onaangezuiverd hebben gelaten. Overeenkomstig het voorstel van den penningmeester wordt besloten eenige in zijne missive genoemde personen op dit verzuim aandachtig te maken en hun beleefdelijk te verzoeken het nog verschuldigde aan te zuiveren.

\section{Uitgave der Babad Tanah Djawi door den heer Meinsma.}

De heer Niemann deelt mede dat de heer Nijhoff zich genegen heeft verklaard het werk uit te geven, op de volgende voorwaarden: met een subsidie van het Instituut ad $f 37,50$ per vel van 16 pagina's, of zonder eenig subsidie van het Instituut indien het departement van kolonien besluiten mocht 200 exemplaren van het werk te bestellen.

Op voorstel van den Voorzitter wordt besloten de heeren Niemann en Kern uit te noodigen een rapport omtrent dit werk op te maken, welk rapport met een schrijven van het Bestuur aan den Minister van Kolonien zal worden toegezonden, waarin het verzoek zal worden gedaan om de uitgave van het werk te ondersteunen.

IV. Benoeming van een Onder-Voorzitter (ter vervanging van den heer Sloet van de Beele, die als bestuurslid is afgetreden) en van een Secretaris (daar de heer Robidé van der Aa om redenen van gezondheid van zijne functien van Secretaris wenscht ontslagen te worden.)

De Voorzitter verzoekt den heer Robidé van der Aa op zijn besluit terug te komen, die echter bij zijn voornemen volhardt, te meer daar zijn toestand vordert dat hij zich gedurende geruimen tijd naar het buitenland begeeft.

Overgaande tot de verkiezing van een Onder-Voorzitter en Secretaris, worden tot die functien verkozen, de heeren: Dr. P. Bleeker en Mr. P. A. S. van Limburg Brouwer, die beide verklaren de hun opgedragen betrekking aan te nemen; de laatste echter niet dan voorloopig en met uitdrukkelijk verzoek, van het secretariaat weer ontslagen te worden zoodra een ander der leden zich daarmede zal kunnen belasten.

V. Resumtie der notulen van de algemeene vergadering van 
12 Juni 1871. Die notulen worden gelezen en goedgekeurd en ter opneming in de Bijdragen bestemd.

VI. Plan van transcriptie van Devanägarî, Javaansch en Arabisch voor werken in de Bijdragen. De heer van Limburg Brouwer legt in naain van de daartoe benoemde commissie een concept over, waarover in de volgende vergadering zal beraadslaagd worden.

VII. Herdruk der Bloemlezing uit Maleische geschriflen van den heer Niemann. De heer Robidé van der Aa zegt dat, naar aanleiding van het door het Bestuur genomen besluit, de herdruk van dit werk ondernomen is, dat het 2e deel bijna is afgedrukt en dat daarna met den herdruk van net le deel terstond een begin zal worden gemaakt.

VIII. Omslagen voor de Bïdragen. De heer Meinsma zegt dat voor de in de $3 \mathrm{e}$ volgreeks uitgegeven deelen der Bijdragen geen omslagen zijn toegezonden aan de leden. Hij meent dat die toezending wenschelijk zou zijn omdat niet alle leden besluiten de Bijdragen te doen inbinden. Aan den Secretaris wordt opgedragen, zoo de uitgave daarvan niet te hoog is, alsnog voor de vijf verschenen deelen omslagen te doen maken en die voor de leden, die ze wenschen te ontvangen, beschikbaar te stellen.

De vergadering wordt door den Voorzitter gesloten.

\section{6 ste BESTUURSVERGADERING.}

\section{September 1871.}

Tegenwoordig de heeren Gevers Deynoot (Voorzitter), Bleeker, van Limburg Brouwer, Bachiene, Dumontier, 's Jacob, Hoffimann, Meinsma en Niemann.

De notulen van het verhandelde in de vorige vergadering worden gelezen en goedgekeurd.

I. Voor de bibliotheek zijn ingezonden de volgende werken: Van het departement van kolonien: 